\title{
Laboratorial analyses of fungal keratitis in a University Service
}

\author{
Análise laboratorial de ceratites fúngicas em Serviço Universitário
}

\author{
Alfredo José Muniz de Andrade ${ }^{(1)}$ \\ Luís Antônio Vieira ${ }^{(2)}$ \\ Ana Luisa Höfling'Lima ${ }^{(3)}$ \\ Maria Cecília Zorat Yu ${ }^{(4)}$ \\ Olga Fischman Gompertz ${ }^{(5)}$ \\ Denise de Freitas ${ }^{(6)}$ \\ Luciene Barbosa de Souza ${ }^{(7)}$
}

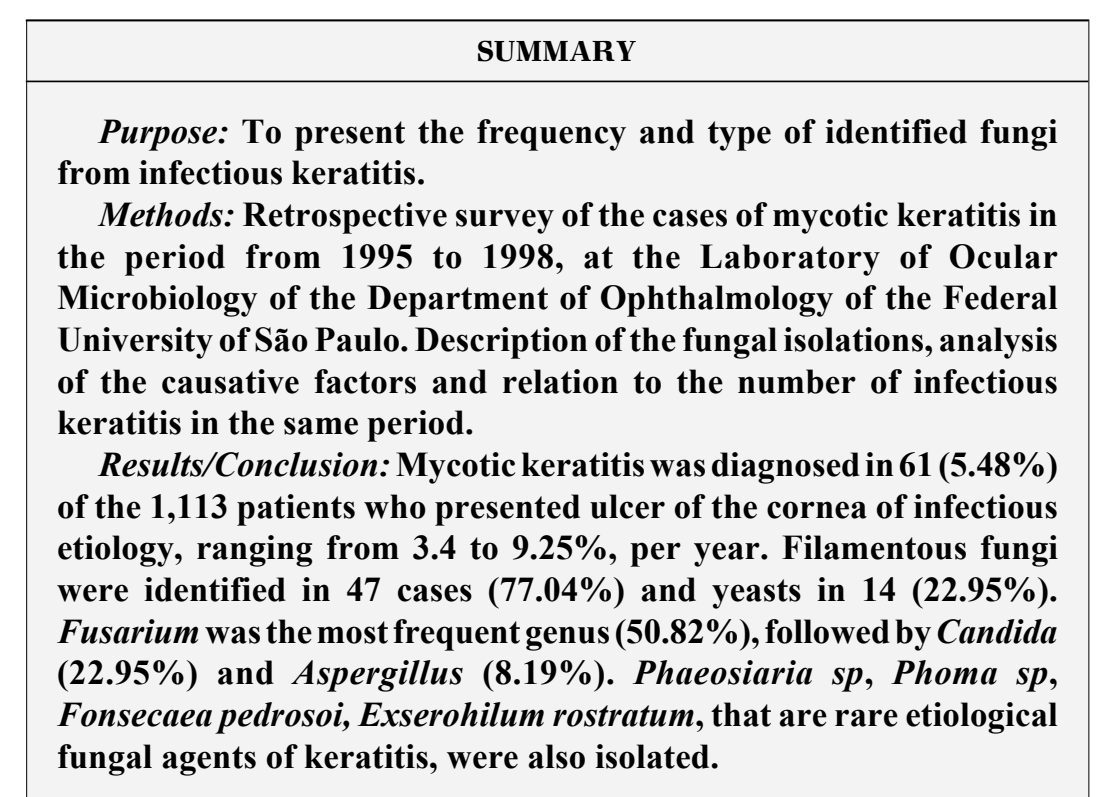

Keywords: Fungal eye infections; Corneal ulcer; Keratitis; Cornea.
Médico Estagiário do Departmento de Oftalmologia da UNIFESP/Escola Paulista de Medicina (EPM).

(2) Doutor em Medicina e Médico Colaborador do Departamento de Oftalmologia da UNIFESP/EPM.

3) Profa. Adjunta-Doutora do Departmento de Oftalmologia da UNIFESP/EPM.

(4) Biomédica do Laboratório de Microbiologia Ocular do Departamento de Oftalmologia da UNIFESP/ EPM.

(5) Profa. Adjunta-Doutora do Departamento de Microbiologia, Imunologia e Parasitologia da UNIFESP/EPM.

(6) Chefe do Setor de Córnea e Doenças Externas do Departamento de Oftalmologia da UNIFESP/EPM.

(7) Profa. do Departamento de Oftalmologia da UNIFESP/EPM.

Endereço para correspondência: Dr. Alfredo José Muniz de Andrade. Av. 11 de Junho 99/63B. São Paulo (SP) Brasil. CEP 04041-000 Fone/Fax: (0xx11) 571-7320. e-mail: aandrade@apm.org.br

\section{INTRODUCTION}

Fungal keratitis is not the most frequent among the suppurative corneal infections ${ }^{1-3}$, however the difficulty of treatment, the problems of fungus identification, the diversity of clinical presentation observed in each case and also new emerging cases each year, make this disease an interesting object of study for many authors. Approximately 60 fungus genera have already been identified as etiologic agents of infectious keratitis ${ }^{1}$. The rural population is generally more prone than the urban one to this type of infection ${ }^{2-4}$ because of the higher probability of exposure to trauma, mainly due to plants.

Fungi are classified, according to their macroscopic characteristics, into filamentous, dimorphic and yeast-like. The first are subdivided into dematiaceous and hyaline. Epidemiological characteristics of ocular infections due to filamentous and yeast-like fungi are different ${ }^{1-3}$. Filamentous fungi appear at a higher frequency in corneal infections in countries near the equator ${ }^{1-3}$, in users of topical corticosteroids ${ }^{4,6}$, in contact lens users ${ }^{6,7}$ and after ocular trauma due to plants ${ }^{4,6}$. Infections due to yeast occur in cold countries and are more frequent in patients who live the poles ${ }^{1-3}$, in therapeutic contact lens users ${ }^{7}$, in eye with previous surgeries and in patients under local or systemic immunosuppression with corticosteriods or immunosuppressants ${ }^{1-3}$. 
The purpose of this study is to report the frequency of positive fungal cultures in infectious keratitis and of the various fungal species identified as etiologic agents in the period from 1995 to 1998 at the Laboratory of Ocular Microbiology, UNIFESP/EPM.

\section{MATERIAL AND METHODS}

The results of laboratory examinations of patients with a diagnosis of infectious keratitis, referred to the Laboratory of Ocular Microbiology, UNIFESP/EPM, during the period from January 1, 1995 to December 31, 1998 were retrospectively analyzed.

Data collected from the charts included: age, sex, identification of the agent through direct examination and culture, information on the history of the infectious process as well as research on factors associated with mycotic ocular infections, such as, use of corticosteroids or previous topic antibiotics, previous eye surgeries, direct eye trauma, use of topic or systemic immunosuppressants and also if the patient was in use or not of cosmetic or therapeutic contact lens.

The Laboratory of Ocular Microbiology, UNIFESP/EPM, receives samples for microbiologic analysis from patients who come to the ophthalmologic complex of UNIFESP.

In all cases, collection of material for analysis was carried out directly from the site of the corneal infection at the Laboratory of Microbiology. Samples were always obtain by trained ophthalmologists, using the Kimura spatula under direct vision through the slit lamp after instillation of anesthetic eye drops. Samples were seeded on the following media: Sabouraud dextrose agar, maintained at room temperature, and chocolate agar, blood agar, brain-heart infusion (BHI), incubated at $37^{\circ} \mathrm{C}$. From the first to the 30th day, media observation was made daily. Cultures which could not be identified by their macroand microbiological aspects were transferred to tubes containing Sabouraud dextrose agar medium for later microscopic study by the process of culture on slides.

The characteristics considered for fungus identification ${ }^{4}$ were macroscopic aspects of texture, coloring, brightness, growth rate and microscopic aspects such as, mycelium and conidium types, relationships between hyphae and fructification organs. Microculture on slides was the technique used for observation of filamentous fungi. The Department of Micology, UNIFESP/EPM was responsible for the identification of all positive growths, with identification of yeast by the technique of assimilation sugar fermentation.

Smears were prepared from each sample for direct examination by Gram and Giemsa methods.

The culture was considered positive when presenting consistent growth of at least two inocula, in two or more media or was also positive on direct examination, that is, with growth in at least one inoculum in one medium.

\section{RESULTS}

Of the 1113 cases of corneal ulcer surveyed during the period between 1995 and 1998 (48 months), in 61 (5.48\%) a fungus was identified as the etiologic agent in these patients. Forty-one patients were males and 20, females, with ages ranging from 12 to 89 years.

Unilateral mycotic infection was observed in 60 patients and in only one patient the infection was bilateral. The direct microscopic examination was positive in $90.2 \%$ of the cases (55/61). Agreement between the findings of direct examination and culture was $87.2 \%(41 / 47)$ in the cases with a diagnosis of infection due to filamentous fungi, and 100,0\% (14/14) in those with a diagnosis of infectious keratitis due to yeast.

Although all plates were observed daily for 30 days, no growth could be detected after the 7 th day.

The annual frequency, in numbers and percentage, of infectious and mycotic keratitis cases with a positive culture is shown in Table 1.

Among the identified filamentous fungi, most were hyaline and Fusarium solani was the most frequent (Table 2).

New dematiaceous fungi as keratitis causing agents were identified: Fonsecaea pedrosoi, Phoma sp, Phaeostaria sp and Exserohilum rostratum (Table2).

The frequency of positive isolations was greater in 1998, both regarding filamentous fungi and yeast (Tables 2 and 3 ).

In general of the isolated fungi, distributed according to genus and in decreasing order, the most frequent were: Fusarium 50.82\% (31/61), Candida 22.95\% (14/61), Aspergillus 8.19\% (05/61), Penicillium 4.91\% (03/61) and Scedosporium 3,27\% (02/61) (Tables 2 and 3$)$.

Table 4 shows the description of facts associated with cases with positive fungal isolations.

\section{DISCUSSION}

Despite its defense mechanisms, the eye is subject to infections, among which the infection of the cornea is an important chapter of modern ophthalmology. The cornea may present suppurative keratitis due to virus, bacteria, parasites and fungi. Fungi are not the most frequent etiologic agents of infectious keratitis. Even if they are not the most frequent type, the diversity of the clinical presentations and difficulty of treatment annually lead to several publications which en-

\begin{tabular}{|c|c|c|}
\hline Keratitis & $\begin{array}{c}\text { Total of infectious } \\
\text { keratitis }\end{array}$ & $\begin{array}{c}\text { Fungal keratitis with } \\
\text { positive cultures }\end{array}$ \\
\hline Year & No. & No. (\%) \\
\hline 1995 & 305 & $16(5.24)$ \\
\hline 1996 & 263 & $13(4.94)$ \\
\hline 1997 & 318 & $11(3.46)$ \\
\hline 1998 & 227 & $21(9.25)$ \\
\hline Total & 1113 & $61(5.48)$ \\
\hline
\end{tabular}




\begin{tabular}{|c|c|c|c|c|c|c|}
\hline & FILAMENTOUS FUNGI & 1995 & 1996 & 1997 & 1998 & TOTAL \\
\hline \multirow{8}{*}{ 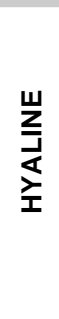 } & Fusarium solani & 10 & 06 & 05 & 05 & 26 \\
\hline & Fusarium spp & 0 & 0 & 0 & 05 & 05 \\
\hline & Penicillium spp & 03 & 0 & 0 & 0 & 03 \\
\hline & Aspergillus flavus & 01 & 0 & 0 & 0 & 01 \\
\hline & Aspergillus fumigatus & 0 & 0 & 0 & 01 & 01 \\
\hline & Aspergillus spp & 01 & 01 & 01 & 0 & 03 \\
\hline & Paecilomyces lilacinus & 0 & 01 & 0 & 0 & 01 \\
\hline & Scedosporium apiospermun & 0 & 0 & 01 & 01 & 02 \\
\hline \multirow{8}{*}{ 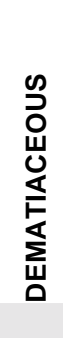 } & TOTAL HYALINE & 15 & 08 & 07 & 12 & 42 \\
\hline & Fonsecaea pedrosoi & 0 & 0 & 0 & 01 & 01 \\
\hline & Phoma sp & 0 & 0 & 0 & 01 & 01 \\
\hline & Madurella $s p$ & 0 & 0 & 0 & 01 & 01 \\
\hline & Phaeosiaria $s p$ & 0 & 01 & 0 & 0 & 01 \\
\hline & Exserohilum rostratum & 0 & 01 & 0 & 0 & 01 \\
\hline & TOTAL DEMATIACEOUS & 0 & 02 & 0 & 03 & 05 \\
\hline & TOTAL FILAMENTOUS FUNGI & 15 & 10 & 07 & 15 & 47 \\
\hline
\end{tabular}

\begin{tabular}{|c|c|c|c|c|c|}
\hline FUNGUS & 1995 & 1996 & 1997 & 1998 & TOTAL \\
\hline Candida albicans & 0 & 02 & 03 & 02 & 07 \\
\hline Candida parapsilosis & 0 & 01 & 01 & 01 & 03 \\
\hline Candida tropicalis & 0 & 0 & 0 & 01 & 01 \\
\hline Candida spp & 01 & 0 & 0 & 02 & 03 \\
\hline TOTAL & 01 & 03 & 04 & 06 & 14 \\
\hline
\end{tabular}

rich knowledge about this issue. Normal conjunctival microbiota usually does not consist of fungi. In some special situations of life or work, individuals exposed to corneal trauma are more prone to develop mycotic infection ${ }^{2,3}$.

Analysis of the data from patients who came to the Laboratory of Microbiology, UNIFESP/EPM, reflects only the internal incidence of the Laboratory and should not be used as an epidemiological datum for the population in general or even for the analysis of the total of infectious keratitis treated at UNIFESP.
The studied population of 41 men and 20 women, with ages ranging from 12 to 89 years, shows the same proportion, regarding sex and age, as observed in other studied mycotic keratitis series.

The frequency of positive cultures, between the years 1995 and 1998 , with a variation of $3.46-9.25 \%$ per year, agrees with the world literature which presents an incidence of 6 $20 \%$ per year of fungal keratitis in relation to other causes of infectious keratitis ${ }^{2,3,6}$. Series with national surveys of mycotic corneal keratitis are rare ${ }^{3,8}$. Increase in mycotic keratitis frequency may be related to a better handling of the samples from the collection to the following of fungal growth, to the indiscriminate use of topic corticosteroids ${ }^{1,2}$. In our series the frequency observed year after year, between 1995 and 1998 does not seem to be increasing.

Among the micotis keratitis cases, filamentous fungi were the most frequent with $77.04 \%(47 / 61)$, these agents being the predicted fungi in warm climates ${ }^{3,4,6}$. Regarding identified fungi, our results agree with those reported for series described in other countries, which show and incidence of 6 to $82 \%$ for Fusarium ${ }^{2,4,6}, 8.2$ to $25.1 \%$ for Candida ${ }^{2,3,6}, 2$ to

\begin{tabular}{|c|c|c|c|c|}
\hline \multirow{3}{*}{ ASSOCIATED FACTORS } & \multicolumn{4}{|c|}{ FUNGI } \\
\hline & \multicolumn{2}{|c|}{ FILAMENTOUS } & \multicolumn{2}{|c|}{ YEAST-LIKE } \\
\hline & $\mathrm{N}=47$ & $(\%)$ & $\mathrm{N}=14$ & $(\%)$ \\
\hline TOPIC ANTIBIOTIC & 26 & $(55.3)$ & 06 & $(42.8)$ \\
\hline TOPIC CORTICOSTEROID & 06 & $(12.7)$ & 0 & $(0)$ \\
\hline TRAUMA RELATED TO CORNEAL ULCER & 20 & $(42.5)$ & 03 & $(21.4)$ \\
\hline USE OF THERAPEUTIC CONTACT LENS & 0 & $(0)$ & 02 & $(14.2)$ \\
\hline IMMUNOSUPPRESSION & 01 & $(2.1)$ & 01 & $(7.1)$ \\
\hline KERATOPLASTIES & 06 & $(12.7)$ & 06 & $(42.8)$ \\
\hline
\end{tabular}


29\% for Penicillium 2,3,6. Fusarium has been the most frequent agent of mycotic keratitis in Latin American countries ${ }^{8.9}$, Colombia and Paraguay, and in the US 6, 7 . Aspergillus has been described as the most frequent in the world literature, with variations between 7.9 and $64 \%{ }^{2,6}$; it was the second, regarding frequency, in our study. Scedosporium was isolated in this series in a greater number of cases $(1.6 \%)$, when compared to that of the $80 \mathrm{~s}^{3}$.

Depending on the climatic variations in a same country, it will be noted that the occurrence of these infections vary according to the regions ${ }^{2,6}$, to the degree of exposure of the population to the risk factors and the origin of the studied population, if urban or rural.

There are no data in Brazil on the frequency of corneal mycotic infections in the various regions as has been observed between the south and the north of the US ${ }^{4,6}$. Our results agree with those of other surveys which also present predominance of filamentous fungi ${ }^{1-3,10}$.

For all studied samples from patients with a diagnostic hypothesis of infectious keratitis, slides were prepared for cytology staining with Giemsa and for direct microbiological examination, with Gram. Correlation between the direct microbiological examination and culture was $90.29 \%(55 / 61)$, suggesting that the direct method, being fast and efficient, associated with the clinical signs, is a good option for initial management orientation. This results presents a greater positivity than that observed in previous studies from the same Service ${ }^{3,10}$, which can eventually be explained solely by improvement in manipulation and sample obtention.

Any situation that promotes loss of corneal epithelium integrity is considered a risk factor for keratitis in general ${ }^{2,3}$. Fungal keratities present the following associated factors: trauma, topic medications, previous corneal surgeries, use of contact lens and chronic keratities. Besides those already described, no new factor has been identified in our series ${ }^{1-3}$.

The first two factors which most frequently occur among patients with filamentous fungus infection were use of topic antibiotics - 55,3\% (26/47) - and previous trauma - 42.5\% (20/ 47). The use of topic antibiotics was identified in a higher number of cases than in former studies by the same laboratory, which presented a frequency between 12.8 and $22 \%{ }^{3,10}$. The great number of patients with corneal infections, and in use of topic antibiotic, who came to the Service, at UNIFESP, is explained by the fact that this Service is a tertiary reference center to which more severe cases that did not respond to initially applied therapy are referred. Since one of the differential diagnoses of suppurative keratitis is bacterial keratitis, the initial therapy with antibiotics is justified in services without supporting laboratory. The frequency of 33 to $100 \%$, described in the literature for mycotic keratitis in patients with corneal trauma, with organic material or foreign bodies ${ }^{2,4,6}$, was confirmed in our series, that is, $42.5 \%$ of the studied population in which the etiologic agents were filamentous fungi.

Among the infections due to yeast, the mostly occurring associated factors were: the use of topic antibiotic - 42.8\% (06/ 14) - and previous surgeries - 42.8\% (06/14), followed by history of trauma - $21.4 \%(03 / 14)$, corroborating what is expected in yeast infections which occur more frequently in eyes with surface alterations ${ }^{1-3}$. Frequency of previous corneal surgery as a factor associated with mycotic keratitis is comparable to that of other reviews ${ }^{1-3}$. In our study a rather significant presence of other factors such as use of contact lenses and previous use of topic antibiotics ${ }^{1-3}$ was not observed, possibly because of the relatively small size of the series.

The variation in the number of fungal keratitis in relation to the diagnosed infectious keratities in the period from 1995 to 1998, at the Laboratory of Ocular Microbiology, UNIFESP/EPM, the most frequently isolated fungus types and their distribution regarding risk factor, age and sex are in agreement with the literature. We observed that the dematiaceous fungi previously had not been diagnosed. We emphasize the importance of the specific identification of yeast for the performance of sensitivity tests to antifungals, since the species present different profiles regarding antimycotics, allowing guidelines for therapeutic management.

\section{RESUMO}

Objetivo: Apresentar a freqüência e o tipo de fungos identificados de infecções corneanas.

Métodos: Levantamento retrospectivo dos casos de ceratites micóticas, no Laboratório de Microbiologia Ocular do Departamento de Oftalmologia da Universidade Federal de São Paulo (UNIFESP) no período entre 1995 a 1998. Descrição dos isolamentos de fungos, análise dos fatores desencadeantes e relação com o número de ceratites infecciosas no mesmo período.

Resultados/Conclusão: Ceratites micóticas foram diagnosticadas em 61 (5,48\%) dos 1113 pacientes que apresentaram úlcera de córnea de etiologia infecciosa, com variação de 3,469,25\%, ao ano. Fungos filamentosos foram identificados em 47 casos (77,04\%) e leveduras em 14 (22,95\%). Fusarium foi o gênero mais freqüente (50,82\%), seguido de Candida (22,95\%) e Aspergillus (8,19\%). Foram também isolados fungos raros como agentes etiológicos de ceratites como: Phaeosiaria sp; Phoma sp; Fonsecaea pedrosoi $e$ Exserohilum rostratum.

Palavras-chave: Infecções oculares micóticas; Úlceras de córnea; Ceratite; Córnea.

\section{REFERENCES}

\footnotetext{
1. Jones DB. Diagnosis and management of fungal keratitis. In: Tasman W, Jaeger EA, eds. Duane's Clinical Ophthalmology. Philadelphia: JB Lippincott, 1998; CD-ROM edition.

2. Alfonso EC, Rosa RH. Fungal keratitis. In: Krachmer JH, Mannis MJ, Holland EJ. Cornea and external disease: clinical diagnosis and management. St. Louis: Mosby, 1997; p.1253-66.

3. Vieira LA. Ceratite micótica. In: Belfort Jr R, Kara-JN. Córnea. Clínica-
} Cirúrgica. São Paulo: Roca, 1997; p.189-203. 
4. Liesegang TJ, Forster RK. Spectrum of microbial keratitis in South Florida. Am J Ophthalmol 1980;90:38-47.

5. De Hoog GS, Guarro J. Atlas of Clinical Fungi, 1st ed. Reus: Centraalbureau voor Schimmelcultures, 1995; 720p.

6. Rosa RH, Miller D, Alfonso EC. The changing spectrum of fungal keratitis in South Florida. Ophthalmology 1994;101:1005-13.

7. Wilhelmus KR, Robinson NM, Font RA, Hamil MB, Jones DB. Fungal keratitis in contact lens wearers. Am J Ophthalmol 1988;106:708-14.
8. Cuero RG. Ecological distribution of Fusarium solani and its opportunistic action related to mycotic keratitis in Cali, Colombia. J Clin Microbiol 1980;12:455-61.

9. Mino de Kaspar H, Zoulek G, Paredes ME, Alborno R, Medina D, Centurion de Morinigo M, Ortiz de Fresco M, Aguero F. Mycotic keratites in Paraguay. Mycoses (Germany) 1991;34:251-411.

10. Lima ALH, Nishi M, Lottemberg CL, Guiudugli T. Úlceras de córnea em serviço de referência. Arq Bras Oftalmol 1988;51:118-20.

\section{CURSO INTERNACIONAL DE GLAUCO
Maksoud Plaza Hotel
Alameda Campinas, $150 \cdot 01404-900 \cdot$ São Paulo - SP \\ Tel. 55-11-253-4411 - Fax: 55-11-253-4544}

\section{4 e 15 de Julho de 2000}

\section{TEMAS QUE SERÃO ABORDADOS}

- Avancos na Perimetria Computadorizada - Novas Drogas no Tratamento

- Cirurgia não penetrante (viscocanalostomia)

- Laser no Glaucoma

- Análise da Camada de Fibras Nervosas

- Implantes e Válvulas

- Topografia do Nervo Óptico

- Diagnóstico Precoce de Glaucoma

- Prevenção e Tratamento de Complicações Cirúrgicas

\section{PALESTRANTES}

Clive S. Migdal - Western Eye Hospital - London - England Mark B. Sherwood - University of Florida - Gainesville, FL - USA

\section{COMISSÃO}

\section{ORGANIZADORA}

Carlos E. L. Arieta - Chefe do Setor de Catarata da UNICAMP

Newton Kara José - Professor Titular do Depto. de Oftalmologia da UNICAMP Vital Paulino Costa - Chefe do Setor de Glaucoma da UNICAMP

I N F O R M A Ç Õ E S : Secretaria Executiva

JDE Comunicacão e Eventos

Al. Santos, 1343 Ci. 304 - CEP $01419-001$ - São Paulo - SP

Tels: $\quad 55-11-289-4301$ / 251-5273

Fax: 55-11-288-8157 _ E-mail: jidecomev@uol.com.br 